\title{
Comparison of Ethanol and Methanol Extracts of Bay Leaves (Syzygium polyanthum) in Terms of Vitamin C, Iron and Phytochemical Levels
}

\author{
Suharni ${ }^{1}$, D Indarto ${ }^{1,2,3}$, and R Cilmiaty ${ }^{1,4}$ \\ \{suharniani733@gmail.com¹,dono@staff.uns.ac.id ${ }^{2}$,h_risya@yahoo.co.id\} \\ Postgraduate Student of Human Nutrition Sciences, Universitas Sebelas Maret, Surakarta ${ }^{1}$, \\ Department of Physiology, Faculty of Medicine, Universitas Sebelas Maret, Surakarta², \\ Biomedical Laboratory, Faculty of Medicine, Universitas Sebelas Maret, Surakarta ${ }^{3}$, \\ Department of Dentistry and Oral Health, General Hospital UNS, Faculty of Medicine, Universitas \\ Sebelas Maret, Surakarta ${ }^{4}$
}

\begin{abstract}
Bay leaves are Indonesian plants, which are often used for cooking spices and have beneficial properties for human health. This study aimed to compare micronutrient and phytochemical contents in bay leaves extract with ethanol or methanol solvent. Vitamin $\mathrm{C}$ and tannins levels were measured using a spectrophotometer, while Fe levels used an Atomic Absorption Spectrophotometer (AAS). The results showed that bay leaves Simplicia contained $14.81 \pm 0.07 \%(\mathrm{w} / \mathrm{w}) \mathrm{Fe}$ and $29.42 \pm 3.76 \%$ vitamin C. Higher levels of $\mathrm{Fe}$, vitamin $\mathrm{C}$, and tannins were also observed in ethanol extract of bay leaves $(9.39 \pm$ $0.05 \%, 0.15 \pm 0.10 \mathrm{ppm}$, and 3,522.63 $\pm 39.7 \mathrm{~d} 3 \mathrm{ppm})$, compared to the methanol extract $(5.34 \pm 0.04 \%, 0.09 \pm 0.11 \mathrm{ppm}$ and 2,306.84 $\pm 18.98 \mathrm{ppm}$. In conclusion, ethanol is a better solvent for extracting bay leaves than methanol to obtain vitamin $\mathrm{C}, \mathrm{Fe}$, and tannins. Further research is required to confirm the anti anemia effect of that extract.
\end{abstract}

Keywords: Bay leaves, Ethanol extract, Vitamin C, Iron, Anemia.

\section{Introduction}

Anemia is a global public health and nutrition issue that affects both poor and industrialized countries. World Health Organization (WHO), anemia affects more than 1.62 billion people worldwide [1]. Anemia affects over $60 \%$ of the world's population, with iron deficiency accounting for the majority of cases [2]. Young women have ten times the risk of anemia than young men [3]. In Indonesia, the prevalence of anemia is $23.9 \%$ in women and $18.4 \%$ higher than in men [4]. Anemia incidence in adolescents in 2013 was $37.1 \%$ and increased to $48.9 \%$ in 2018, with the highest rate in the 15-24 year age group (84.6\%) [5]. To control anemia, World Health Organization (WHO) targets a 50\% reduction in anemia in women of childbearing age 15-49 years by 2025 [6].

Anemia diseases can have an impact on human health, social development, and economic growth [3]. Inadequate iron consumption, poor iron absorption, and increased iron requirements during pregnancy, development, and nursing can lead to iron deficiency anemia (IDA) [7]. Iron loss during menstruation puts women of reproductive age at risk for IDA, with an average loss of $35 \mathrm{~mL}$ of blood equivalent to $16 \mathrm{mg}$ of iron every month [2]. Anemia is also a common sign of micronutrient deficiency and a country's poor health [8]. Oral iron supplementation hasn't 
completely cured the condition. Alternatives to anemia treatment need due to side effects such as diarrhea, nausea, vomiting, and headaches [9].

In recent years, herbal medicine has been used to reduce the incidence of anemia. Bay leaves are widely spread in Indonesia and are widely used for a cooking spice because it has a distinctive taste [10]. Bay leaves can be an alternative treatment for anemia because they contain complete nutrients such as protein, iron, vitamin $\mathrm{C}$, riboflavin and niasin, which can play a role in metabolism. Every $100 \mathrm{~g}$ of dry bay leaves simplicia contains $44.1 \mathrm{mg}$ of iron [11] [12]. The results of in vivo research with a duration of administration of bay leaf extract for 14 days at a dose of $2.2 \mathrm{mg}$ can increase $\mathrm{Hb}$ levels by $2.4 \mathrm{~g} \%$, an amount of $4.4 \mathrm{mg}$ by $1.55 \mathrm{~g} \%$, and a dose of $6.6 \mathrm{mg}$ with an increase in Hb levels of $2.65 \mathrm{~g} \%$ in Wistar strain mice, comparable to the standard treatment of blood supplemented tablets [13]. Bay leaves are safe for consumption because they are proven not to show toxic, teratogenicity, and genotoxic effects in experimental animal [14]. However, the micronutrient content in bay leaves extract is still unknown. Therefore, this study aimed to identify $\mathrm{Fe}$, vitamin $\mathrm{C}$, and tannins contents in the bay leaves.

\section{Research Methods}

\subsection{Materials}

Fresh bay leaves were obtained from the herbal sales canter of Merapi Farma Pakem, Sleman Yogyakarta. All reagents used in the study were bought from Merck Germany unless otherwise stated, whereas $\mathrm{HNO} 3$, aqua dest, Na2CO3, and Folin Ciocalten reagents were provided by the Laboratory of Pharmaceutical Biology and Pharmacology, Ahmad Dahlan University, Yogyakarta.

\subsection{Extraction of Bay Leaves}

Fresh bay leaves were washed with tap water and then dried in a closed room for seven days. Selected dry leaves were grounded using a hammer mill and then sieved with 40 mesh. Bay leaves Simplicia were extracted with $70 \%$ ethanol or $100 \%$ methanol using the maceration method with a 1:5 ratio. The extraction step was repeated twice to get a higher iron concentration. Bay leaves suspension was then filtered with $0.45 \mu \mathrm{m}$ membrane paper, and the supernatant was dried with a rotary vacuum evaporator at $50{ }^{\circ} \mathrm{C} 60$ minutes. The yield of bay leaves extracts was calculated with a formula:

$$
\text { Yield }=(\text { Weighted extract }) /(\text { Weighted Simplicia })=100 \%
$$

\subsection{Quantification of Micronutrient Levels in Bay leaves Simplicia and Extract}

Iron and vitamin C levels in a bay leave Simplicia were measured using Atomic Absorption Spectrophotometry (AAS) and titration assay conducted at the Chem-Mix Pratama Laboratory

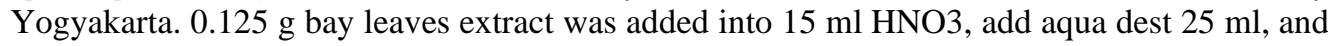
Atomic Absorption Spectrophotometry (AAS) analyzed with a wavelength of $248.4 \mathrm{~nm}$. To measure vitamin c using the titration method, $10 \mathrm{~g}$ of bay leaves Simplicia was dissolved with aquadest $100 \mathrm{ml}$ and then filtered by centrifugation. The diluted solution was input into $5-25$ $\mathrm{ml}$ Erlenmeyer and added with $2 \mathrm{ml}$ of $1 \%$ alum. Finally, the mixed solution was titrated with 
$0.01 \mathrm{~N}$ iodine until it turns blue-violet [15].

For quantification of iron levels in bay leaves extract was conducted at the Integrated Research and Examination Laboratory Gadjah Mada University Yogyakarta with the same method as described before. In contrast, Vitamin $\mathrm{C}$ levels were examined using the spectrophotometer method. In brief, $100 \mathrm{mg}$ bay leaf extract was dissolved in $5 \mathrm{~mL}$ aquabidest and directly measured using a spectrophotometer at 200-400 nm wavelength [16].

\subsection{Quantification of Tannins Levels}

A total amount of $100 \mathrm{mg}$ bay leaves extract was dissolved in $2 \mathrm{ml}$ aqua dest and was filtered to get a clear supernatant. After that, the supernatant was diluted with aqua dest to achieve a 5 $\mathrm{ml}$ final concentration. $300 \mu \mathrm{L}$ diluted bay leaves extract was added to $1.5 \mathrm{~mL}$ Folin Ciocalteau reagent and shook thoroughly for 3 minutes. $1.2 \mathrm{~mL}$ of $7.5 \% \mathrm{Na} 2 \mathrm{CO} 3$ solution was added into the previous solution and was then incubated for 1 hour at room temperature. Finally, the mixed solution was read with a spectrophotometer at $600-800 \mathrm{~nm}$ wavelength.

\section{Results and Discussion}

Table 1 presented the results of bay leaves extraction using ethanol $70 \%$ and $100 \%$ methanol. The extract yield using $70 \%$ ethanol was similar to the extract yield using $100 \%$ methanol. Our research findings

Table 1. Yield Bay Leaves Extract using $70 \%$ Ethanol and 100\% Methanol

\begin{tabular}{llllll}
\hline & Fresh Weight $(\mathrm{kg})$ & Dry Weight $(\mathrm{kg})$ & Simplicia $(\mathrm{g})$ & Extract $(\mathrm{g})$ & Yield $(\%)$ \\
\hline Ethanol & 2.000 & 1.200 & 250 & 83.7 & 33.2 \\
Methanol & 2.000 & 1.200 & 250 & 80.6 & 32.12 \\
\hline
\end{tabular}

Where different from the previous research findings ethanol and methanol. The yield of ethanol extract of bay leaves in our study was higher than in the last survey $(10,56 \%)$ [17]. The yield of methanol extract with a ratio of bay leaves simplicia and solvent (1:1) obtained a yield of $27.03 \%$ [18]. One of the causes of the high yield in this study is the comparison of the number of samples with solvent. The results showed that the yield of ethanol was $33.3 \%$ and methanol 33. $12 \%$, with a comparison of simplicia bay leaves with solvent (1:5). The more solvent is added, the contact between the material and the solvent that serves as the extraction medium will result in a high extract yield [19].

To figure out the macronutrient composition, we analyzed $\mathrm{Fe}$ and vitamin $\mathrm{C}$ levels in bay leaves simplicia. Table 2 indicated that the Vitamin $C$ levels in basin leave Simplicia were higher than the Fe levels in bay goes simplicia. In comparison to the food composition from the Indonesian ministry of health, Fe levels in our simplicia were lower than Fe levels in the food composition $(44.1 \mathrm{mg} / 100 \mathrm{~g})$, while the vitamin C levels were higher than that of the food composition $(0.40 \mathrm{mg} / 100 \mathrm{~g})$. Fe analyzed method by AAS and vitamin $\mathrm{C}$ with titration [12]. While the results of the study in Table 2 obtained Fe of $14.81 \pm 0.07 \mathrm{mg} / 100 \mathrm{~g}$ analyzed with the AAS method and vitamin C $29.42 \pm 3.76 \mathrm{mg} / 100 \mathrm{~g}$ by titration. The research finding in our study is different from the Basir study [20], in which vitamin $\mathrm{C}$ levels in bay leaves simplicia are $0.55 \%$. 
Table 2. Results of $\mathrm{Fe}$ and Vitamin $\mathrm{C}$ levels in Bay Leaves Simplicia.

\begin{tabular}{lc}
\hline Bay Leaves Simplicia & $\mathrm{mg} / 100 \mathrm{~g}$ \\
\hline $\mathrm{Fe}$ & $14.81 \pm 0.07$ \\
Vitamin C & $29.42 \pm 3.76$ \\
\hline
\end{tabular}

Iron levels in a bay leave simplicia from our study are only $14.81 \pm 0.07 \mathrm{mg} / 100 \mathrm{~g}$, which is insufficient to meet the iron daily need for adult women $(18 \mathrm{mg} /$ day) [21]. Iron $(\mathrm{Fe})$ is a micromineral necessary for the formation of red blood cells [22]. Therefore, it requires extraction of bay leaves simplicia to enhance iron concentration [23]. The result of our study shows that ethanol extraction of bay leaves contains $30.09 \mathrm{mg} / 100 \mathrm{~g} \mathrm{Fe}$, more significant than the methanol extract of bay leaves. Ethanol solution has $\mathrm{OH}$ group polar and $\mathrm{CH} 2 \mathrm{CH} 3$ group non-polar, which the opposing group can attract active compounds in the bay leaves extract. In addition, ethanol solvent has several characteristics: low toxicity, neutral charge, and sound absorption. The ethanol can be mixed with water in various ratios that can inhibit $>20 \%$ germs growth [24]. Meanwhile, methanol solvent is avoided further extraction because of its acute and chronic toxicity [25].

Table 3. Results of Fe, Vitamin C, and Tannins Concentrations in Bay Leaves Extract.

\begin{tabular}{lcl}
\hline & $70 \%$ Ethanol & $100 \%$ Methanol \\
\hline Fe $^{\mathrm{a}}$ & $30.09 \mathrm{mg} / 100 \mathrm{~g}$ & $0.09 \pm 0.11(\mathrm{ppm})$ \\
${\text { Vitamin C }(\%)^{\mathrm{b}}}$ & $9.39 \pm 0.05$ & $5.34 \pm 0.04$ \\
${\text { Tannins }(\mathrm{ppm})^{\mathrm{c}}}^{\mathrm{C}}$ & $3,522.63 \pm 39.73$ & $2,306.84 \pm 18.98$ \\
\hline
\end{tabular}

a AAS
b Spectrophotometer
c Spectrophotometer

We further analyzed the Fe, vitamin $\mathrm{C}$, and tannin levels in bay leaves extract using the $70 \%$ ethanol and $100 \%$ methanol with the maceration method (Table 2). In general, ethanol extract of bay leaves had higher levels of vitamin C $(9.39 \pm 0.05 \%)$ and tannins $(3,522.63 \pm 39.73 \mathrm{ppm})$, compared to methanol extract of bay leaves $(5.34 \pm 0.04 \%$ and 2,306.84 $\pm 18.98 \mathrm{ppm}$ respectively). To our knowledge, we have not yet found any publication related to $\mathrm{Fe}$ and vitamin $\mathrm{C}$ levels in bay leave extract. Bay leaves are a rich vitamin $\mathrm{C}$ source that can help iron absorption by converting $\mathrm{Fe}^{3+}$ into $\mathrm{Fe}^{2+}$ in the presence of the duodenal cytochrome $\mathrm{B}$ reductase (DCYTB) enzyme [22].

Bay leaves also contain phytochemical compounds. Tannins are one of the phenolic compounds and also in plants act as a defense against microorganisms [26]. Another study showed that the tannin content with ethanol solvent was $0.1688 \%$, acetone $0.1452 \%$, and water extract $0.62 \%$ by maceration method with a ratio of $50 \mathrm{~g}$ sample and $500 \mathrm{ml}$ solvent until a liquid extract is obtained [27]. The higher the amount of solvent used, the removing the target compound into the solvent can occur more optimally [19]. The results of our research in the form of thick extract using maceration method with a ratio of sample and solvent (1:5) obtained tannin content $(3.522 .63 \pm 39.73 \mathrm{ppm})$ ethanol and $(2.306 .84 \pm 18.97 \mathrm{ppm})$ methanol solvent.

Fresh bay leaves sample used in this study was a mixture of old and young leaves. The category of leaves can influence the high tannin of bay leaves. Old leaves have very high tannins 
compared to young leaves [28]. The environment in which it grows can also affect plant analysis of the chemical content of plants [27]. Cultivated crops may be more controlled for various aspects that reduce the quality [25].

\section{Conclusion}

Maceration of bay leaves using ethanol and methanol solvents yields similar extracts, but the ethanol extract has higher Fe, vitamin $\mathrm{C}$, and tannins levels than the methanol extract. In addition, bay leaves Simplicia has lower Fe and vitamin $\mathrm{C}$ levels than the bay go excerpts. In the future, ethanol extract can be used for Fe supplementation combined with other high $\mathrm{Fe}$ extracts.

Acknowledgements. The authors would like to thank the Laboratory of Pharmaceutical Biology and Pharmacology, Ahmad Dahlan University, Yogyakarta, Integrated Research and Examination Laboratory Gadjah Mada University Yogyakarta, and Chem-Mix Pratama Laboratory Yogyakarta for testing micronutrients and phytochemicals in our extractions and simplicia.

\section{References}

[1] WHO. The global prevalence of anaemia in 2011. Geneva: World Health Organization; 2015 pp. $1-48$.

[2] Kassebaum N J. The Global Burden of Anemia. Hematol Oncol Clin North Am. 2016 ; 30: 247308.

[3] Mulyani Y and Sari D N. The Effect of Dragon Fruit Juice and Honey on the Improvement of Pregnant Women's Hb. Strada Jurnal Kesehatan. 2020; 9 (2) : 1409-1414.

[4] Kemenkes RI. Riset Kesehatan Dasar 2013. Jakarta; Badan Penelitian dan Pengembangan Kesehatan Kementrian Kesehatan Republik Indonesia; 2013.

[5] Kemenkes RI. Laporan Nasional Kesehatan Dasar 2018. Jakarta: Badan Penelitian dan Pengembangan Kesehatan; 2018.

[6] WHO. Global Anaemia Reduction Efforts Among Women of Reproductive Age: Impact, Achievement of Targets and the way Forward for Optimizing Efforts. Geneva: World Health Organization; 2020.

[7] Short M, Domagalski J E. Iron Deficiency Anemia: Evaluation and Management American Family Physician. Am. Fam. Physician. 2013; 87 (2): 98-104.

[8] Bappenas. Kajian Sektor Kesehatan Pembangunan Gizi di Indonesia. Jakarta; Di Rektorat Kesehatan dan Gizi Masyarakat Kedeputian Pembanguan Manusia, Masyarakat dan Kebudayaan Kementerian Perencanaan Pembangunan Nasional; 2019.

[9] Hermayanti D, Setiawan W and Azhar R M. The Effect Of Moringa Leaf (Moringa Oleifera Lam) and Vitamin C Combination Extract in Improving Anemia Indicators Deficiency of White Rice Iron Male Diet Low Rice Iron. Saintika Med. 2020; 16 (2): 104-114.

[10] Rahim E N A A, Ismail A, Omar M N, Rahmat U N dan Ahmad W A N. GC-MS Analysis of Phytochemical Compounds in Syzygium polyanthum Leaves Extracted using UltrasoundAssisted Method Pharmacognosy Journal. 2018; 10 (1): 110-119.

[11] Karim, Kasthuri, and Nordini Nadiatul. Vitamins and Mineral Contents of Ten Selected Weeds and Local Plants of Kelantan, Malaysia. IJBPAS. 2017; 6(2): 161-174.

[12] Kemenkes RI. Tabel Komposisi Pangan Indonesia 2017. Jakarta; Direktorat Jenderal Kesehatan Masyarakat Direktorat Gizi Masyarakat; 2018.

[13] Adyani K, Anwar A D and Rohmawaty E. Peningkatan Kadar Hemoglobin dengan Pemberian Ekstrak Daun Salam (Syzygium Polyanthum (Wight) Walp) pada Tikus Model Anemia Defisiensi 
Besi Majalah Kedokteran Bandung. 2018; 50 (3): 167-172.

[14] Jumaat SR, Tajuddin S N, Sudmoon R, Chaveerach C, Abdullah U H, and Mohamed R. Chemical constituents and toxicity screening of three aromatic plant species from Peninsular Malaysia BioResources. 2017; 12 (3): 5878-5896.

[15] Fitriana Y A N dan Fitri A S. Analysis of Vitamin C Levels in Citrus Fruits using the Iodometric Titration Method. Sainteks. 2020; 17 (1): 27-32.

[16] Hidayah N W N, Dewi A O T and Aviv A N 2020 Penetapan Kadar Vitamin C pada Ekstrak Daun Pepaya (Carica Papaya L.) Muda dan Tua dengan Metode Spektrofotometri UV-Vis Farmasindo. 2020; 4 (1): 2548-6667.

[17] Rudiana T, Inriatmoko D and Komariah. Aktivitas Antioksidan Kombinasi Ekstrak Etanol Daun Salam ( Syzygium polyanthum ) dan Daun Kelor. 2020; 25 (1): 20-22.

[18] Wilapangga A and Sari L N. Analisis Fitokimia dan Antioksidan Metode DPPH Ekstrak Metanol Daun Salam (Eugenia Polyantha) Ijobb. 2018; 2 (1): 19-24.

[19] Noviyanty, Salingkat C A and Syamsiar. The Effect of Solvent Ratio to the Quality of Extracts from the Red Dragon Fruit Peel ( Hylocereus polyrhizus ). Kovalen. 2019; 5 (3): 280-289.

[20] Basir Hernawati. Penetapan Kadar Vitamin C pada Daun Salam (Syzygium Polyanthum) secara Idometri. Jurnal Kesehatan. 2018; 2 (1): 1-4.

[21] Kemenkes RI. Peraturan Mentri Kesehatan Republik Indoneisa Nomor 28 tahun 2019 tentang Angka Kecukupan Gizi Mayarakat Indonesia. Jakarta; Direktur Jenderal Peraturan Perundangundangan Kementerian Hukum dan Hak asasi Manusia Republik Indonesia; 2019.

[22] Ansharullah A, Musfiroh D A, Natsir M, Maulidiyah and Nurdin M. Engineering in Agriculture, Environment and Food Improving the Fe and vitamin $\mathrm{C}$ content of the sago-based liquid sugar with Moringa and Katuk leaf extracts. Eng. Agric. Environ. Food. 2019; 12 (4): 494-498.

[23] Zhang Q W, Lin L G and Ye W C. Techniques for extraction and isolation of natural products: A comprehensive review Chinese Med.2018; 13 (1): 1-26.

[24] Rizki A U, Cholid C and Amalia M. Perbedaan Efektivitas Ekstrak RimpangTemulawak (Curcuma xanthorriza Roxb.) dengan Ekstrak Daun Salam(Eugenia polyantha Wight) pada Penurunan Kadar Kolesterol Total Tiksu Putih Jantan (Rattus norvegicus) J. Profesi Med. J. Kedokt. dan Kesehat. 2017; 10 (1): 54- 69.

[25] Malik. Karakterisasi Ekstrak Etanol Daun Salam ( Syzygium polyanthum Wight) Dari Tiga Tempat Tumbuh di Indonesia. 2014. Skripsi UIN Syarif Hidayatullah Jakarta.

[26] War A. R, Paular A, Buhroo A, A, Hussain B, Ignacimuthu S and Sharma H C. Mechanisms of Plant Defense against Insect Herbivores. plant signaling and behavior. 2012; 7 (4); 1306-1320.

[27] Rivai H, Yulianti S and Chandra B. Qualitative and Quantitative Analysis of Hexane Acetone, Ethanol and Water Extract from Bay Leaves ( Syzygium polyanthum (Wight )Walp) Pharm. Chemical. 2019; 6 (3): 13-20.

[28] Rahman N, Bahriul P and Diah A. Uji Aktivitas Antioksidan Ekstrak Daun Salam (Syzygium Polyanthum) dengan Menggunanakan 1,1-Difenil-2-Pikrilhidrazil J. Akad. Kim. 2014; 3 (3): 143 149. 